\title{
Why There Will Be No Peak Coal in the Foreseeable Future
}

\author{
Thomas Thielemann ${ }^{1}$, Hans-Wilhelm Schiffer ${ }^{2}$ \\ ${ }^{1}$ Coal Mining, RWE Power AG, Essen/Cologne, Germany \\ ${ }^{2}$ General Economic Policy/Science, RWE AG, Essen, Germany \\ Email: thomas.thielemann@rwe.com
}

Received January 10, 2012; revised February 22, 2012; accepted March 19, 2012

\begin{abstract}
Hard coal and lignite—also referred to here jointly as coal—play a central role in the worldwide supply of humanity with primary energy. As a fossil energy carrier, coal is one of the finite natural resources. The reach of the world's coal reserves is significant, and coal has the potential to cover some of the global energy and raw-material needs at least into the $22^{\text {nd }}$ century. Precondition for this is a sustainable energy policy, i.e. an equal-ranking view of the goals of environmental and climate compatibility (sustainability), security of supply and competitiveness (affordability). The focus of developments is on resource efficiency and energy savings to obtain more modern and more efficient coal-based power plants. Greater use of coal translates into higher $\mathrm{CO}_{2}$ emissions. So if we are to achieve the climate-protection goals of limiting the rise in temperatures and reducing the $\mathrm{CO}_{2}$ content in the Earth's atmosphere, the launch of CCS technology is recommended. Within the scope of the climate-protection debate, a discussion is also underway about an alleged drying up of coal availability in the short term (under the heading of "peak coal"). This discussion is an example of how, from the limited perspective of particular interests, a swathe of facts can be ignored. Hence, this article sets out to take a fact-based, sober look at the subject of the "reach of global coal reserves". How much coal do we really have? And to what extent will coal be available tomorrow to guarantee secure and affordable energy supplies in the future as well? These issues will be investigated here.
\end{abstract}

Keywords: Coal; Hard Coal; Lignite; Reserves; Resources; Mining; Exploration; Trade; CCS

\section{Introduction}

Hard coal and lignite are the non-renewable energy raw materials with the largest reserves worldwide [1]. After crude oil, coal occupies slot two in the world's primary-energy consumption, with a share of $30 \%$ in 2010 [2]. Coal is mainly used in power generation (electricity). In $2010,41 \%$ of global power generation was based on coal [3]. In fact, since 2000 the world demand for coal has been growing at $4 \% / \mathrm{a}$ on average, faster than for oil (1\%/a) and natural gas (2\%/a) [2]. By 2010, worldwide 1.4 billion people still had no access to electricity. This blatantly argues for a continuing increase in cheap electricity production from coal in the future.

Despite this central role in the world's energy supply, the weight of coal in the future energy mix is being controversially discussed, especially in Europe. Within the scope of the climate debate, the use of coal is being viewed critically by environmentalists, above all on account of its fairly high specific $\mathrm{CO}_{2}$ emissions. Still, worldwide coal output rose by $1.4 \%$ to $6823 \mathrm{mill} \cdot \mathrm{t}$ despite the global financial crisis in 2009 and by $6.0 \%$ to
7229 mill $\cdot t$ in 2010. Of this, 6186 mill·t was hard coal and 1043 mill·t lignite [4]. The worldwide extraction of hard coals, in particular, grew disproportionately in recent decades. It was up from 2798 mill·t in 1980, to 3493 mill-t in 1990 and 3587 mill $\cdot t$ in 2000 to approx. 6186 mill·t in 2010. From 1980 to 2010, this was an explosion up to $221 \%$. These figures give a first impression of the international coal-mining sector's ability to expand rapidly and to adapt to world demand.

As regards Germany, hard-coal imports were up 15\% between 2009 and 2010. This was a response to the economic recovery after the financial crisis. Germany's hard-coal consumption climbed by 8 mill-tce in 2010 to 57.8 mill-tce (tce $=$ metric tonnes of coal equivalent). In 2010, this growth alone was greater than the total energy contribution from photovoltaics and wind power in Germany [5].

A comparison of energy carriers shows that the consumption of lignite and hard coal releases more $\mathrm{CO}_{2}$ emissions than the use of other fossil energy sources. Hence the great importance attached to the use of modern, highly efficient technologies in power plants and the de- 
ployment of CCS technology, including the permanent storage of $\mathrm{CO}_{2}$ in deep geological structures to ensure sustainable climate protection [6]. The energy carrier coal with its extensive reserves will offer an environmentally compatible energy supply well into the future.

\section{Classification of Coal Reserves}

Depending on raw material and deposit, people have experienced some exhaustion of the deposits of specific raw materials across decades, so that, early on, thinking began to focus on the size and the scale of raw-material deposits. With the birth of mining science (mine surveying, geology), a scientifically precise approach gained weight from the 16th century on [7].

Nowadays, data on worldwide coal reserves are captured, assessed and interpreted by a number of institutions. The deposit classifications, originally over 150 in number, can largely be subsumed in the framework classification of the United Nations UNFC [8,9] and in the JORC code $[10,11]$. The two classifications have different objectives. While the UNFC classification pursues, inter alia, governments' needs to provide overviews of the deposits of entire regions and their degree of exploration, the JORC code serves both the technical requirements of mine operators and the financial evaluation of projects to provide investors and banks with economic benchmark data.

A number of institutions produce annually updated compilations of the country-specific scale of reserves and resources. These include the IEA [12], BP [2], the WEC [13] and the BGR [14]. In this respect, the two lastnamed publications contain updated data whereas, in the main, the other publications merely quote figures from the WEC and BGR sources.

Every year, the world consumes large amounts of fossil energy raw materials. To ensure a sufficient supply of these raw materials at all times, stockpiling is necessary. For this purpose, mining companies secure their annual output for several decades by exploring and developing raw-material deposits [15]. These developed quantities which are economically minable using today's technologies and at current prices, are called "reserves". Here, it must be noted that it makes no economic sense for companies to develop raw materials as reserves today already that would extend the reach across 20 to 40 years, depending on the raw material. As soon as reserves are accessible for 20 to 40 years, (frequently physically adjoining) raw-material quantities - even if they could be economically developed today already-usually go undeveloped. These quantities do exist, however, and will ensure a continuous inflow of new reserves in future as well (Figure 1).

"Resources", by contrast, comprise not-yet explored

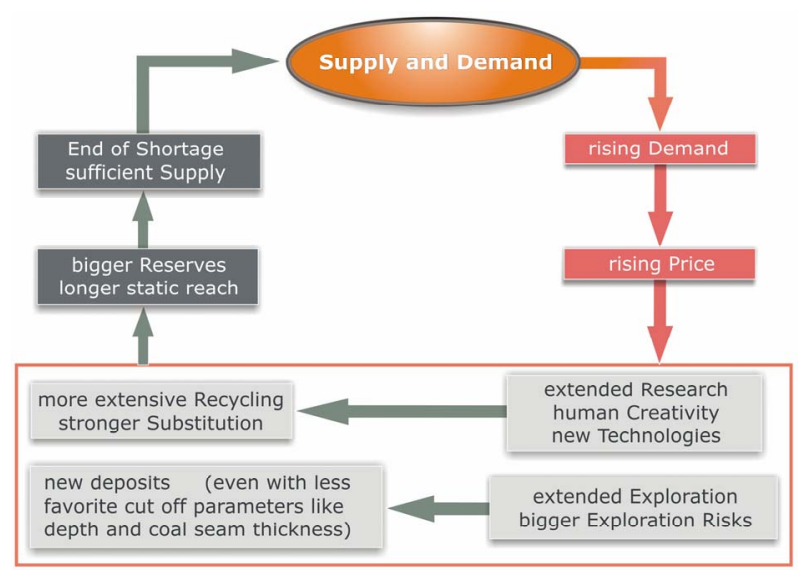

Figure 1. Self-regulating (coal) raw-material cycle, based on [16].

and not-yet economically minable quantities as well as assumed (in-situ) quantities whose scale has not yet been established by exploration or with only little precision. Some of these resources are converted into reserves every year, since both knowledge about coal deposits rises and new pits or pit sections are developed. This replacement of extracted and consumed reserves with "succeeding" resources may be above or below annual output. If the balance is positive, the static reach of a raw material increases. If the balance is negative, the static reach declines. [1] refer to the sum of reserves and resources as "remaining potential" but also as "total resources”.

\section{Quantification of Worldwide Coal Reserves}

Lignite and hard coal are quantified with the aid of a series of cut-off parameters (boundary parameters) as reserves and resources. These include, above all, seam thickness, depth, energy content, interstratified dirt bands and ash content, rank and the share of volatile matter. Coals with a gross calorific value of some $<6000 \mathrm{kcal} / \mathrm{kg}$ are referred to as lignite. Upward of a gross calorific value $>6000 \mathrm{kcal} / \mathrm{kg}$, we speak of hard coals. Anthracite for the sake of simplicity is allocated to the hard coals. Total resources as a rule include seam thicknesses upward of $60 \mathrm{~cm}$. Workability can vary from country to country. [17] includes coals down to a depth of $1800 \mathrm{~m}$ among total resources. At present, however, a mining depth of $1000 \mathrm{~m}$ appears to be the lower threshold for economic, subsidy-free extraction. Depending on these cut-off parameters, lignite and hard-coal deposits can be further sub-divided, as Figure 2 shows for hard coals.

Depending on the use and weighting of different cut-off parameters, the quantity of coal reserves and resources varies considerably in a pit or deposit. This was illustrated and compiled by [17] by way of example for 


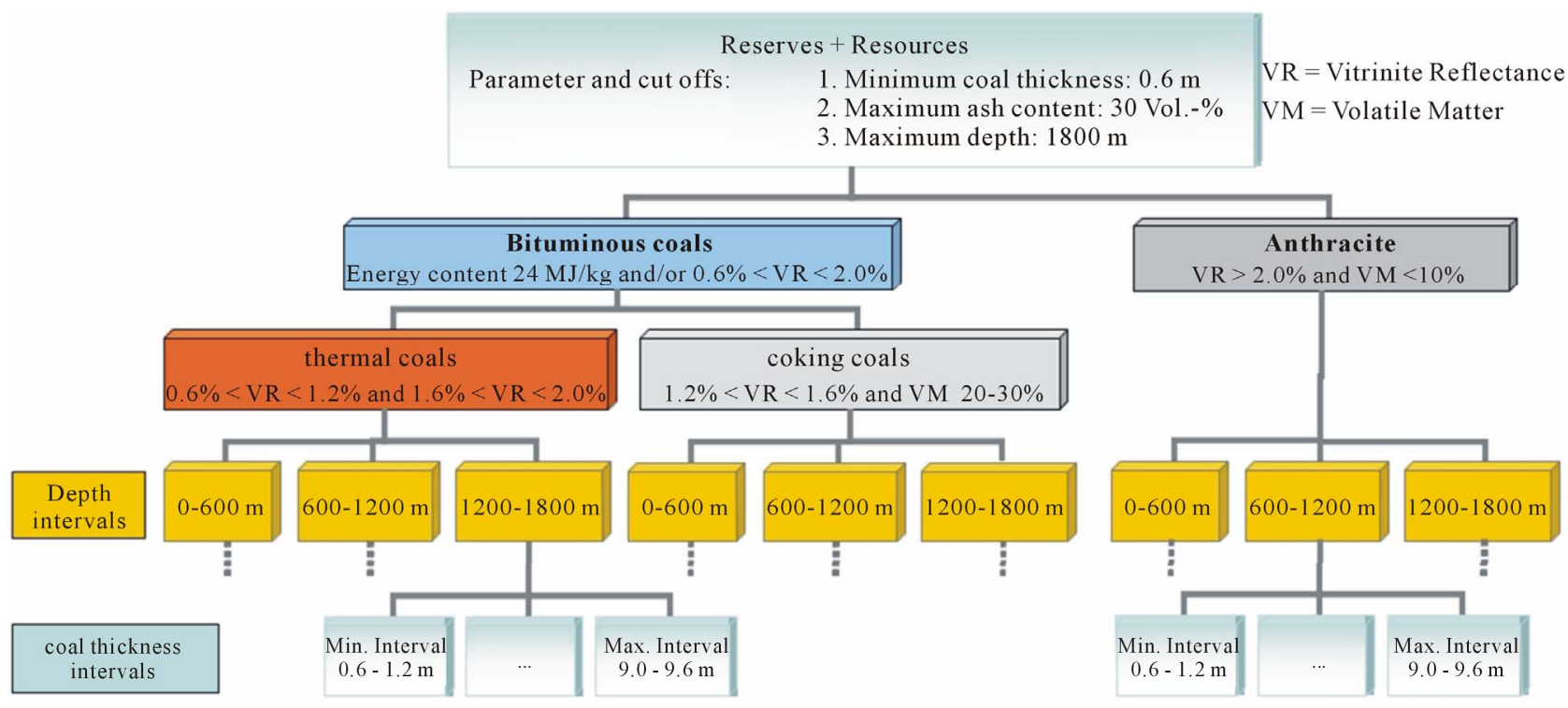

Figure 2. Sub-division of total hard-coal resources, amended according to [17].

the four hard-coal mining areas of the Ukrainian-Russian Donbass basin, the German Ruhr basin, the Polish Upper Silesian basin and the Russian Kuzbass basin. A look at the total resources there, down to a depth of $1800 \mathrm{~m}$, also with quite thin seams down to $60 \mathrm{~cm}$, reveals the total resource quantities shown in Figure 3. However, if we introduce more restrictive cut-off parameters, total resources are reduced in the four sediment basins named above by between 39\% and as much as 91\% (Figure 4). The latter figure stems from the Donbass basin and reflects the great depth and the frequently low seam thickness of the coals in this deposit.

\section{Dynamism in the Statistics}

According to [13], world coal reserves nearly doubled from $591 \mathrm{bn} \cdot \mathrm{t}$ in 1972 to a maximum of $1039 \mathrm{bn} \cdot \mathrm{t}$ in 1990. In the following years, the conversion rates from resource into reserve stood at only $5 \%-20 \%$ of annual world coal output [16]. With hard-coal pits being shut down in Germany, the UK and Poland, say, access to some reserves has been abandoned. In these three countries alone, hard-coal reserves have fallen by $110 \mathrm{bn} \cdot \mathrm{t}$ since 1990 [18]. [19] notes that at the start of the 21st century, too, only a small part of annual output was being replaced by conversion from resource to reserve, e.g. in the form of pit extensions and the commissioning of new mines. This explains the (incorrect) assumption of [20] regarding rapidly falling coal-reserve figures in future.

In fact, the scale of the world's coal reserves depends heavily on price. Rising prices lead to more extensive exploration, economic re-assessment of deposits and, hence, growing reserves (Figure 1). This is particularly true of hard coal. In the period from 1980 to 2004, real hard-coal prices tended to stagnate or fall. This reduced the interest in exploration and explains the declining reserve figures. Companies had sufficient reserves to cover their requirements. Especially with the economic upswing in China, coal demand climbed, however. The same is true of hard-coal prices, both for steam and coking coals. This brought a profound change in the mining companies' interest after 2004. Investment funds were made available to tackle existing coal deposits and to explore and develop new deposits. According to [21], the effect was that, compared with the 2001/2002 fiscal year, spending on exploration in Australia skyrocketed by $366 \%$ to nearly $235 \mathrm{mill} \cdot \mathrm{A} \$$ in fiscal 2007/2008 (Figure 5).

There are similar reports from several countries. China's and Australia's reserves, for instance, rose from 2004 to 2009 by at least double-digit billion-ton amounts. The coal quantities mined in these six years were surpassed by the growth in reserves by a factor of at least 10 .

For future developments in the annual extraction quantities of hard coals, [22] as well as [20] postulate in near-real time a trend like that being discussed for crude oil under the heading "peak oil” or for natural gas under "peak gas". It is assumed here that annual extraction quantities grow over time and then fall again, similar to a normal distribution. This concept, presented by geophysicist M. K. Hubbert in 1956, is also referred to as the Hubbert curve (http://en.wikipedia.org/wiki/Hubbert_curve). For crude oil, this concept is likely to apply, also because the RRR (reserves recovery rate) has been negative roughly since 1980 . This means that, since 1980 , more oil has been extracted worldwide than new reserves found. The new-find rates for oil are limited by geo- 

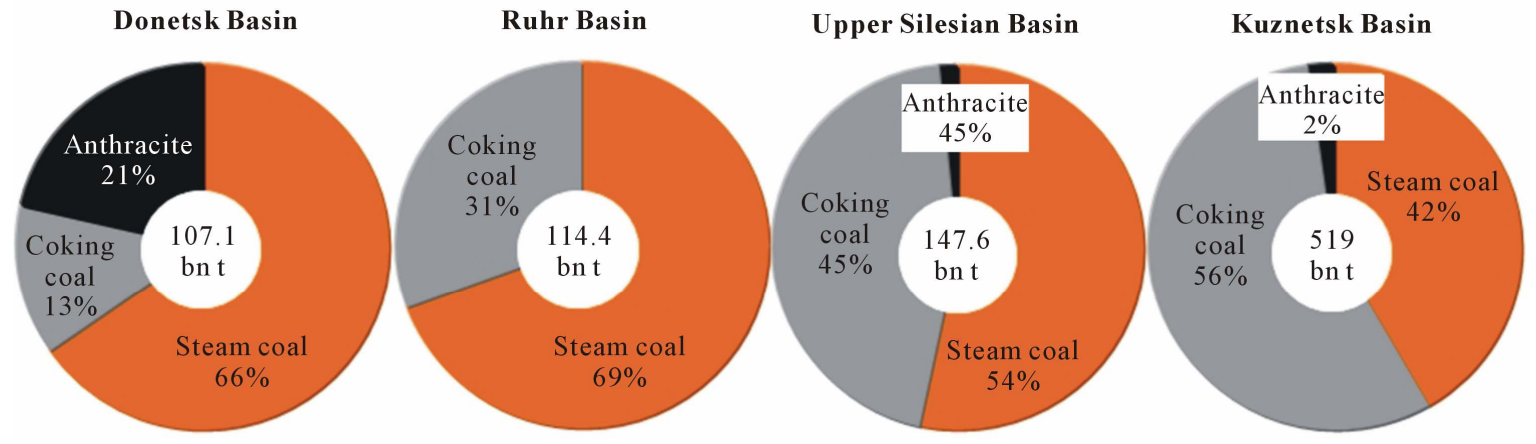

Figure 3. Total resources in four hard-coal deposits with cut-off parameters of $60 \mathrm{~cm}$ seam thickness and $1800 \mathrm{~m}$ depth; amended according to [17].

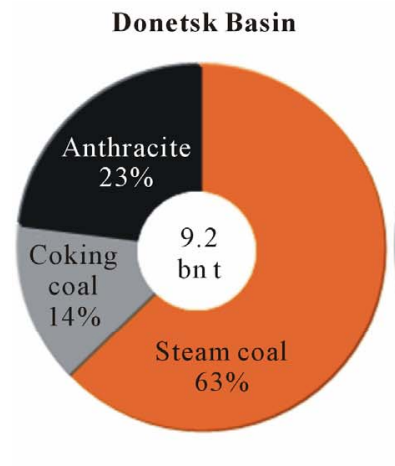

$-91 \%$

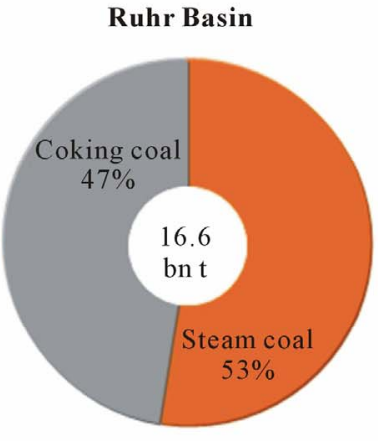

$-85 \%$

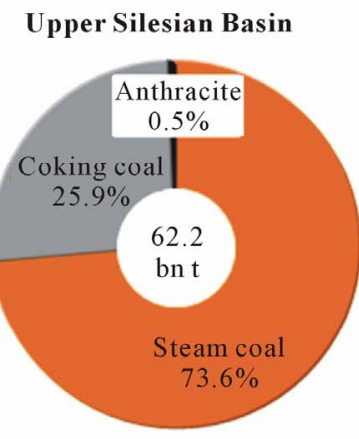

$-58 \%$

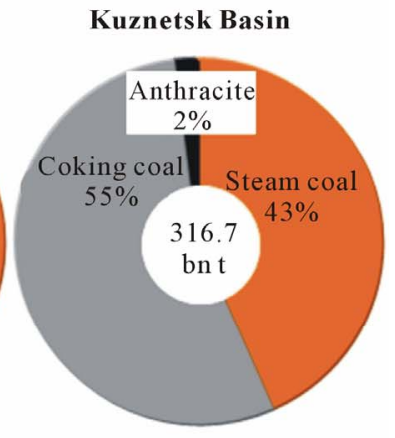

$-39 \%$

Figure 4. Total resources in four hard-coal deposits with more stringent cut-off parameters compared with Figure 3 of 120 $\mathrm{cm}$ seam thickness and $1200 \mathrm{~m}$ depth. This entails the marked percentage share of quantity reductions; according to [17].

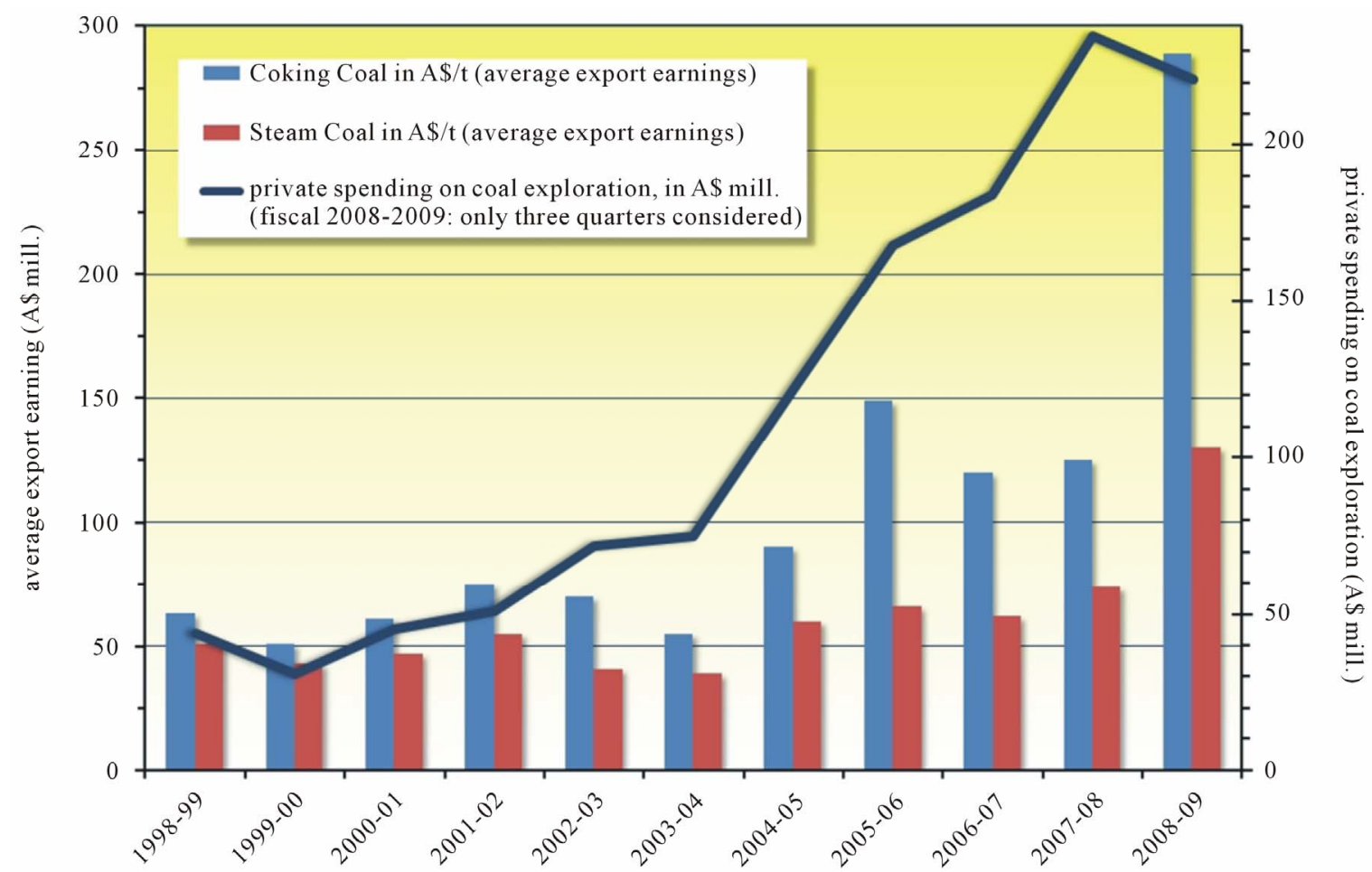

Figure 5. Spending on exploration and export earnings from the sale of hard coal in Australia, 1998 to 2009; according to [21], modified from [1]. 
science and technology.

The case is different for hard coals and lignite. Unlike oil and gas, they are solids. Their exploration has no geoscientific and technical limits. Coals in the Earth's crust can only be eliminated naturally by subduction, including metamorphosis, or by erosion. Other geological processes that may have destructive effects on oil and gas deposits (e.g. chemical cracking by sinking in greater depths, destruction of trap structures through tectonics or erosion) may increase the rank of coals. The deposits themselves survive, however. This being so, global coal reserves and resources are greater by magnitudes than those of oil and gas.

Some publications interpret the fluctuations in the data on the coal deposits of specific countries as alleged proof that this energy form will have to recede by analogy with the fossil energy carriers crude oil and natural gas in the global scale of their use (so-called peak-coal concept, see $[20,23]$. [20] are reckoning with an occurrence of "peak coal" in the period 2020 to 2050. At the same time they concede that their forecasts will only be correct if global political decisions (e.g. for climate-protection reasons) limit the use of coal. Should these decisions fail to materialize and, at the same time, more coal resources be converted into reserves, then [20], too, believe that further rises in annual output quantities are possible. This applies in particular to China as the country with the world's most extensive coal use [24]. As the most recent UN climate conferences, in Copenhagen 2009, Cancún 2010, and in Durban 2011, have shown, no definite political stipulations that would significantly limit the use of coal are foreseeable (http://de.wikipedia.org/wiki/Klimakonferenz). Hence, it must be assumed that coal consumption (Figure 7), which has been growing strongly since 2000, can and will continue to rise.
An illustration of world extraction costs for hard coals was produced at E.ON by Rademacher and Gruß covering $710 \mathrm{bn} \cdot t$, published in [18]. This suggests that, for the best-accessible $150 \mathrm{bn} \cdot \mathrm{t}$, extraction costs are at an estimated US\$19 to 94/t, free pit (in 2007 US\$). Given today's demand for some $6 \mathrm{bn} \cdot \mathrm{t} / \mathrm{a}$, this quantity suffices for about 25 years (Figure 6).

The next $500 \mathrm{bn} \cdot \mathrm{t}$, according to [18], can be produced for about US\$28 to 150/t and, were annual output constant, this would suffice for just under 85 years more. Finally, we have $60 \mathrm{bn} \cdot \mathrm{t}$ which, as things stand today, are minable at much higher costs of some US\$ 50 to 450/t (in 2007 US\$) (Figure 6). This last group of reserves is likely to be even larger if, pursuant to [14], world hard-coal reserves do not amount to 710, but to approx. $723 \mathrm{bn} \cdot \mathrm{t}$. Consequently, hard-coal reserves will suffice until well after 2100 .

\section{World Coal Market}

Hard-coal output reaches record highs nearly every yeardespite the most recent financial crisis. For instance, output was up from 3587 mill·t in 2000 by $72 \%$ to approx. 6186 mill.t in 2010. Lignite production remains at a stable level of around 1000 mill·t every year (Figure 7). This shows the ability of the mining sector and the world market to cover world energy demand for coal even where the rates of increase are high. The only potential limit is the speed of infrastructure expansion. IEA [12] assumes in its New Policies Scenario that in the period 2010 to 2035 around 720 billion US\$ (in 2010-US\$) will be invested globally to expand coal-supply infrastructure. Two thirds of these investments are expected to take place in non-OECD countries, especially in China.

The main locations for producing lignite are Germany, China and Turkey. For hard coal, they are China, the US

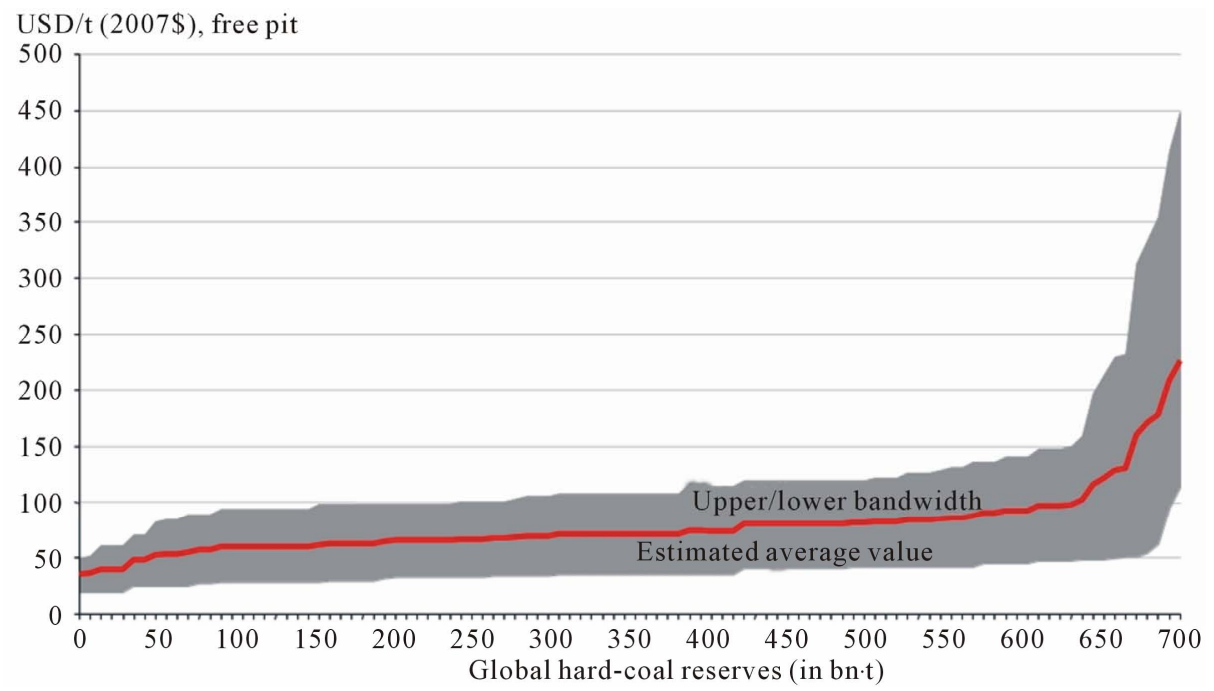

Figure 6. Extraction-cost curve for worldwide hard-coal reserves, from [18]. 


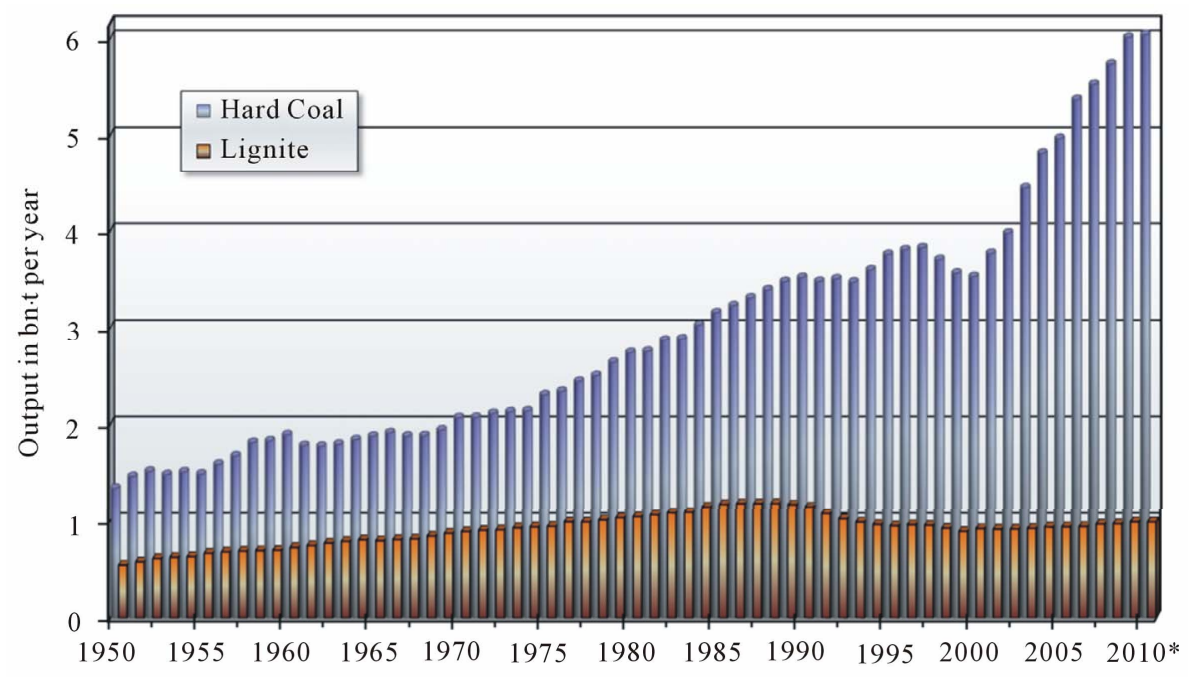

Figure 7. World annual output of hard coal and lignite, 1950-2010; according to authors own data and to [14,25]. * provisional figures.

and India (Figure 8).

Since the 1920s, there has been a developing world market for hard coals. After the second oil crisis in 1979, maritime trade in hard coal enjoyed a practically uninterrupted upswing. Between 1995 and 2005, the volume of maritime trade doubled to $790 \mathrm{mill} \cdot \mathrm{t}$ [19,27]. By 2010, another 22\% was added to a volume of 963 mill.t. Here, Australia's ports exported $300 \mathrm{mill} \cdot \mathrm{t}$, i.e. $31 \%$ of the global maritime trading volume (Figure 9). The volume of maritime trade will continue to grow in future, even if it was not possible in early 2011 to export $8 \mathrm{mill} \cdot \mathrm{t}$ of hard coals due to flooding in Queensland and even if Japan's 2011 demand is likely to be some $10 \mathrm{mill} \cdot \mathrm{t}$ lower owing to the damage to power plants caused by the earthquake and tsunami in that country on 11.03.2011.

Maritime trade has expanded by up to $8 \%$ p.a. since 2000 [28]. In future, the hard-coal deposits of southern Africa will increasingly supply coal for exports. Asian investors, in particular, are developing the local reserves. Starting in 2011, some 2 mill-t/a will go to India from Mozambique. South Africa is expanding the capacity of its biggest export port, Richards Bay, to boost its quantities from currently $68 \mathrm{mill} \cdot \mathrm{t} / \mathrm{a}$ (Figure 9) to $90 \mathrm{mill} \cdot \mathrm{t} / \mathrm{a}$ after 2012. Botswana intends to export coal from its Morupule and Mmamabula deposits to Namibia's deepsea port, Walvis Bay. Chinese investors are active in Tanzania and Zimbabwe with the aim of building up export quantities of $10 \mathrm{mill} \cdot \mathrm{t} / \mathrm{a}$ [29].

If mines and transhipment ports expand, the remaining infrastructure, too, must be adapted. Hence, the Panama Canal is currently being widened from 2007 to 2015 to accommodate ships in the Capesize class in addition to Panamax ships. All in all, this will involve moving 130 $\mathrm{mill} \cdot \mathrm{m}^{3}$ of rock, or 10 times the amount of material moved for the construction of the new 60-km-long Swiss
Gotthard Tunnel [30]. This project will permit the Pacific and Atlantic maritime-trade market to grow further together and expand.

Europe's hard-coal and lignite reserves are also of strategic importance. The dependence of the EU-27 on energy imports continues to grow. Coals mitigate this trend and form $80 \%$ of the reserves of fossil energy sources in the EU-27. They offer security of supply with low price fluctuations (compared with oil and gas). Coal mining allows value-add directly in the EU-27. The coal industry employs some 280,000 in the EU [31].

\section{Upshot}

The global reserves and resources of lignite and hard coals are significantly larger than those of oil and gas, because the solid coal withstands geodynamic processes much better than the fluids oil and gas. World annual production of coals is crucially determined by demand, as is investment in exploration. Investment is not determined by the size of the reserves themselves. Even with strongly rising demand, coal reserves have the potential to cover demand securely into the next century. The regional distribution of the coal deposits in the world shows high diversification. Hence, a high degree of security of supply is ensured even if political unrest occurs in specific regions.

Production capacities and the infrastructure for worldwide hard-coal exports are being expanded at breakneck speed. Consequently, it must be assumed today that lignite and hard-coal production will go on rising and that global maritime trade in hard coals will exceed the 1 bn·t/a mark in a few years' time.

Coal is the fossil energy carrier with the biggest increases in consumption at present. Worldwide, it is the 


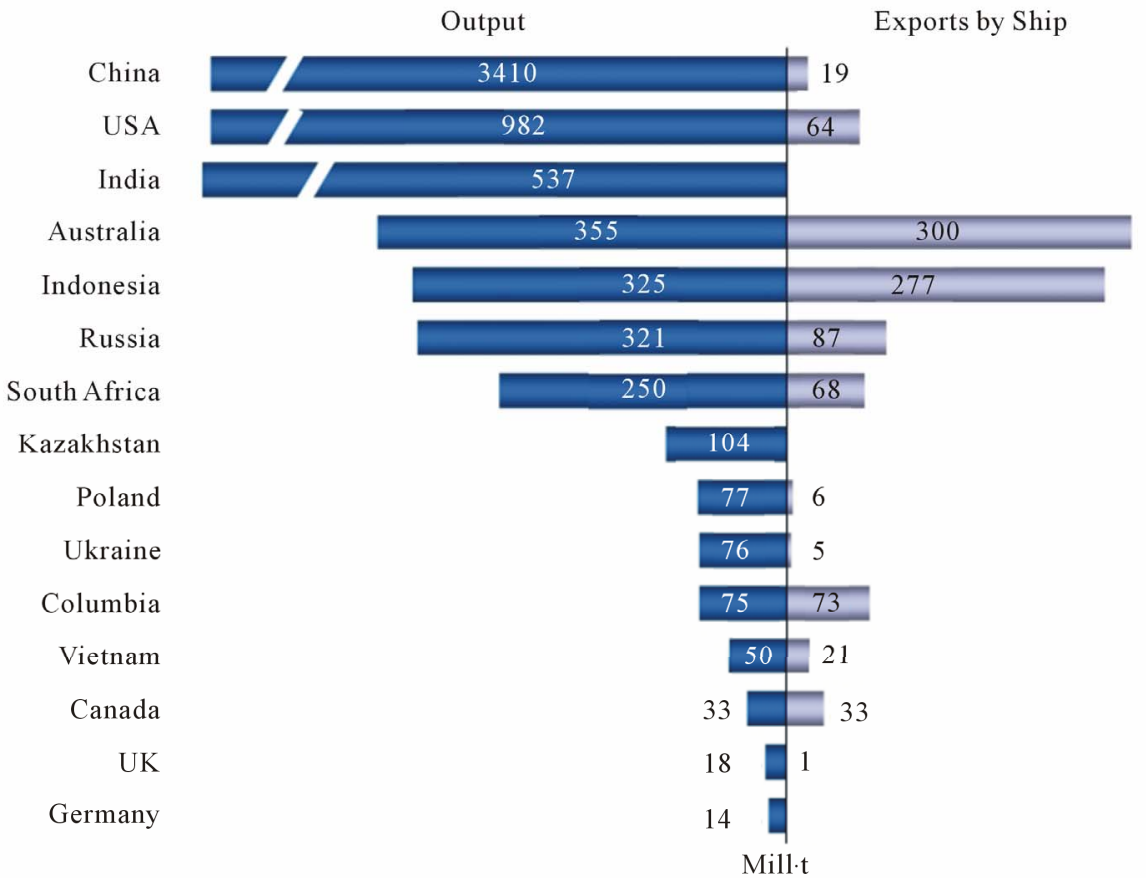

Figure 8. Output and maritime exports of hard coal, 2010, in major countries; from [18], updated according to [26].

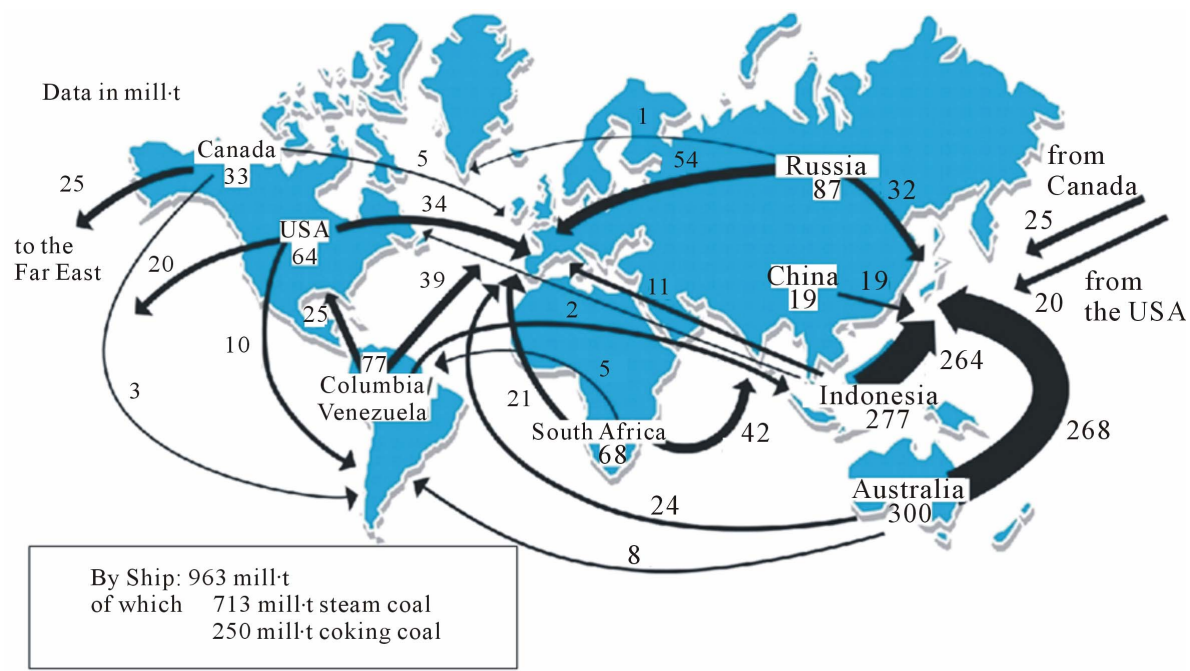

Figure 9. Hard coal trade flows by ship, 2010; from [18], updated according to [26].

no. 1 source for power generation. It is secure, dependable, available, and affordable. This being so, its use is definitely rising, above all in the fast-growing emerging markets. Coal is indispensable in a diversified energy mix. It lowers import dependency. With the further development of CCS technology, sustainable deployment is ensured under climate-protection standpoint as well.

Finally, returning to the initial question as to why there will be no peak coal in the foreseeable future: it is unlikely that the use of coal will be restricted worldwide, so that its expansion would be prevented politically. Hard coal and lignite can make a secure contribution to an environmentally-compatible energy and raw-material supply well beyond the year 2100 .

\section{REFERENCES}

[1] S. Schmidt, S. Rehder and B. Cramer; "Quo Vadis Kohle?” Commodity Top News of the BGR, Hannover, Vol. 32, 2009, p. 10.

[2] BP, "BP Statistical Review of World Energy 2011," London, 2011, p. 45.

http://www.bp.com/assets/bp_internet/globalbp/globalbp_ uk_english/reports_and_publications/statistical_energy_re view_2011/STAGING/local_assets/pdf/statistical_review 
_of_world_energy_full_report_2011.pdf

[3] IEA, "Electricity Information,” International Energy Agency, Paris, 2011, p. 878.

http://www.iea.org/w/bookshop/b.aspx?Subject=Electricit y, ISBN 978-92-64-101913

[4] IEA, “Coal Information 2011,” International Energy Agency, Paris, 2011, p. 542. http://www.iea.org/w/bookshop/add.aspx?id=579

[5] K. Van de Loo and K. Gutberlet, "Steinkohle. Trends auf den Internationalen Steinkohlemärkten,” BWK, das EnergieFachmagazin, Vol. 63, No. 4, 2011, pp. 68-75.

[6] EU, "Sustainable Development in the European Union," Eurostat Report, Brussels, 2009, p. 311.

http://epp.eurostat.ec.europa.eu/portal/page/portal/product _details/publication?p_product_code=KS-78-09-865

[7] G. Agricola, "De re Metallica," VDI-Verlag, Wiesbaden, Reprint of the Edition First Published in 1556, 2006, p. 564.

[8] G. B. L. Fettweis, D. Kelter and R. Nöstaller, "Zur Beurteilung und Klassifizierung von Lagerstättenvorrätendie neue UN-Klassifikation,” Bergund Hüttenmännische Monatshefte, Vol. 144, No. 2, 1999, pp. 43-51.

[9] M. Ersoy, "Worldwide Implementation of United Nations Framework Classification on Coal Deposits," Regional Seminar on UNFC-Application to Energy and Mineral Resources, Moscow, 24-25 April 2003.

http://www.unece.org/energy/se/pdfs/MoscowApr03/erso y.pdf

[10] H. Akin, "Zur Akzeptanz der Geostatistik als Grundlage der Vorratsklassifikation,” In: GDMB, Ed., Klassifikation von Lagerstättenvorräten-Stand der internationalen Bemühungen 1997, Clausthal-Zellerfeld, Vol. 79, 1997, pp. 9-20.

[11] JORC, “Australasian Code for Reporting of Exploration Results, Mineral Resources and Ore Reserves (The JORC Code)," 2004 Edition, 2004, p. 20. http://www.jorc.org/pdf/jorc2004print_v2.pdf

[12] IEA, “World Energy Outlook 2010,” International Energy Agency, Paris, 2010, p. 590. http://www.worldenergyoutlook.org

[13] WEC, “Survey of Energy Resources 2010," A Report of the World Energy Council (WEC), London, 2010, p. 618. http://www.worldenergy.org/publications/3040.asp

[14] BGR, "Reserven, Ressourcen und Verfügbarkeit von Energierohstoffen 2010,” Brief Study, Hannover, 2010, p. 85. http://www.bgr.bund.de

[15] J. P. Gerling and F.-W. Wellmer, "Raw Material Availability-With a Focus on Fossil Energy Resources," World of Mining—Surface \& Underground, Vol. 56, No. 4, 2004, pp. 254-262.

[16] T. Thielemann, S. Schmidt and J. P. Gerling, "Lignite and Hard Coal: Energy Suppliers for World Needs until the Year 2100-An Outlook,” International Journal of Coal Geology, Vol. 72, No. 1, 2007, pp. 1-14. doi:10.1016/j.coal.2007.04.003

[17] S. Schmidt, "Harmonisierung der Reserven- und Ressour-
cen-Einschätzungen von Hartkohlen in Europa und Russland,” Ph.D. Thesis, University of Aachen, Aachen, 2007, p. 441.

[18] H.-W. Schiffer, "Vorratssituation der fossilen Energieträger,” Bergbau, Vol. 9, 2009, pp. 389-393.

[19] C. Kopal, “Angebot und Nachfrage am Steinkohlenweltmarkt,” Zeitschrift für Energiewirtschaft (ZfE), Vol. 30, No. 1, 2006, pp. 67-82.

[20] M. Höök, W. Zittel, J. Schindler and K. Aleklett, "Global Coal Production Outlooks Based on a Logistic Model,” Fuel, Vol. 89, No. 11, 2010, pp. 3546-3558. doi:10.1016/j.fuel.2010.06.013

[21] ABARE, “Australian Mineral Statistics,” Historical Data, 2009.

http://www.abareconomics.com/publications_html/data/d ata/data.html

http://www.abareconomics.com/interactive/10ams_mar/e xcel/ams_tables.xls

[22] M. Höök and K. Aleklett, "Historical Trends in American Coal Production and a Possible Future Outlook,” International Journal of Coal Geology, Vol. 78, No. 3, 2009, pp. 201-216. doi:10.1016/j.coal.2009.03.002

[23] EWG, “Coal: Resources and Future Production,” Report of the Energy Watch Group (EWG), EWG-Series No. 1, Ottobrunn, 2007, p. 47.

[24] B. Q. Lin and J. H. Liu, "Estimating Coal Production Peak and Trends of Coal Imports in China,” Energy Policy, Vol. 38, No. 1, 2010, pp. 512-519. doi:10.1016/j.enpol.2009.09.042

[25] BGR, “Energierohstoffe 2009,” Reserven, Ressourcen, Verfügbarkeit, Hannover, 2009, p. 286. http://www.bgr.bund.de

[26] VDKi, “Annual Report 2011,” Verein der Kohlenimporteure, Hamburg, 2011, p. 130. http://www.verein-kohlenimporteure.de/wDeutsch/jahres bericht/index.php?navid=19

[27] H.-W. Schiffer and C. Kopal, "Beitrag des SteinkohlenWelthandels zur Sicherung der Energieversorgung,” Zeitschrift für Energiewirtschaft, Vol. 29, No. 3, 2005, pp. 171-180.

[28] T. Thielemann, J. P. Gerling, H. Rempel and B. Stribrny, "Entwicklung und Perspektiven des Weltsteinkohlemarktes,” Energiewirtschaftliche Tagesfragen, Vol. 56, No. 1, 2006, pp. S15-S20.

[29] BZ, “Südafrika wird Asiens Kohlegrube,” Report in the German Newspaper Börsen-Zeitung, 29 March 2011, p. 12.

[30] VDI, "Durchbruch am neuen Panamakanal," Report in the German newspaper VDI-Nachrichten, No. 17, 29 April 2011.

[31] B. Ricketts, “Towards 2050: Coal in a Changing World,” VDKi, Hamburg, 14 January 2011.

http://www.verein-kohlenimporteure.de/wDeutsch/aktuell es/meldungen/2011_01_27_72361729_meldung.php?navt ext=Aktuelles 